\title{
Estetika Ragam Tengkuluk Pakaian Tradisional Masyarakat Melayu Jambi
}

\author{
Hartati M ${ }^{1}$, Fatonah ${ }^{2}$, Selfi Mahat Putri ${ }^{3}$ \\ ${ }_{1,2,3}$ Prodi Ilmu Sejarah, Fakultas Ilmu Budaya, Universitas Jambi \\ Email: hartati59@gmail.com, fatonah.nurdin@unja.ac.id, selfi.m.putri@gmail.com
}

\begin{abstract}
Abstrak. Penelitian ini bertujuan untuk mengetahui sejarah dan nilai-nilai estetika tengkuluk sebagai pakaian tradisional perempuan melayu Jambi. Manfaat dari penelitian ini diharapkan bisa menjadi salah satu inventarisasi budaya melayu Jambi dalam ranah ilmiah. Metode yang digunakan dalam penelitian ini merupakan metode kualitatif dengan pendekatan interaksi simbolik. Dengan latar belakang keanekaragaman kekayaan alam dan budaya yang dimiliki oleh provinsi Jambi, terdapat nilainilai keindahan, falsafah dan nilai-nilai estetika budaya. Salah satunya estetika dalam penutup kepala tekuluk/tengkuluk merupakan bagian penting dalam pakaian tradisional perempuan melayu Jambi. Dalam pemakaian tengkuluk sebagai simbol penutup kepala memiliki makna filosofi yang erat dengan adat tradisi dan islam. Masuknya Islam di tanah melayu Jambi mempengaruhi konsep adat dalam pemakaian hiasan kepala prempuan melayu Jambi. Dapat disimpulkan tengkuluk bukan hanya sebagai hiasan kepala namun juga sebagai penutup aurat perempuan Melayu Jambi yang diinvetarisasi dalam seloko adat Jambi “Adat Bersendi Syara', Syara' Bersendi kitabullah. Syara' Mengato, Adat Memakai.” Seloko adat tersebut merupakan nilai filosofi dalam seni estetika mengikat tengkuluk perempuan melayu Jambi yang memiliki keunikan dari nilai estika dan artistika tanpa menggunakan bantuan peniti atau bentul. Selain itu, ketika Islam sudah berkembang di tanah melayu, baju kurung dan tengkuluk menjadi satu kepaduan yang berfungsi bukan hanya sekadar sebagai penutup kepala atau pembungkus tubuh, namun sudah keharusan sebagai identitas jatidiri muslimah melayu, tengkuluk menjadi bagian penutup aurat perempuan sesuai dengan syariat Islam yang berkembang di tanah melayu.
\end{abstract}

Kata Kunci: Tengkuluk; Kuluk; Tekuluk; Budaya; Malayu; Jambi

Abstract. This study aims to determine the history and aesthetic values of tengkuluk as the traditional costumes of Malay women in Jambi. The benefits of this research are expected to be one of the inventory cultural of Malay culture in Jambi, in the scope scientific science. The method in this study was qualitative method with a symbolic interaction approach. With the background of the diversity of natural and cultural wealth possessed by the Jambi province, there covers some values of beauty, philosophy and cultural aesthetic values. One of the aesthetics of the tekuluk / tengkuluk is as headgear that has an important part in the traditional costumes of Malay women in Jambi. The use of tengkuluk as a symbol of the head covering has a philosophical meaning that was closely related to traditional customs and Islamic. The entry of Islamic in the Malay land affected the concept of custom in using of female Malay headgear in Jambi. It can be concluded that tengkuluk was not only as a headgear but also as a cover for part of the body which is forbidden to see, which were inventoried in the Jambi traditional seloko which is "Adat Bersendi Syara', Syara' Bersendi Kitabullah. Syara' Mengato, Adat Memakai.” That rhymes became a philosophical value in the art of aesthetic tying for Malay women in Jambi which had a uniqueness of aesthetic and artistic values without using the help of a safety pin. In addition, when Islam had developed in Malay landl, the clothes of the brackets and tengkuluk became one cohesion that functioned not only as a head covering or body wrap, but it was a necessity as the identity of Malay Muslim identity, the tengkuluk became a part of the female genitalia in accordance with Islamic law thriving in Malay land.

Keywords: Headgear; Tengkuluk; Kuluk; Tekuluk; Culture; Malay; Jambi

\section{PENDAHULUAN}

Pakaian merupakan kulit sosial dan kebudayaan. Pakaian adalah bentuk ekspresi dari identitas seseorang. Pakaian juga berperan besar dalam menentukan citra seseorang. Sadar atau tidak sadar, mau tidak mau, kita menaruh harapan besar bahwa pakaian dapat menggambarkan denagn jelas indentitas kita (Henk Schulte Nordholt, dalam Dwi Ratna Nurhajarini "Kain Kebaya dan Rok Pakaian Perempuan Yogyakarta Awal Abad ke-20).

Pakaian tradisonal dapat menjadi ciri kebudayaan tertentu dalam suatu masyarakat. Secara umum, fungsi pakaian untuk menutup tubuh. Kemudian muncul berbagai aksesoris dan ciri khas yang membedakan antara suatu masyarakat denagan masyarakat lainnya. Salah satunya yaitu Tengkuluk atau Tekuluk yang merupakan penutup kepala dan biasa digunakan oleh perempuan di Jambi untuk dipakai saat keseharian dan juga acara adat.

Tengkuluk atau Tekuluk (tutup kepala) sebagai bagian penting dalam pakaian yang dipakai oleh perempuan Jambi terdiri dari etnik dengan ragam budaya penduduk asli dan pendatang tampak indah dan anggun, merupakan kebanggaan masyarakat Jambi sebagai masyarakat yang berkebudayaan tinggi. Menampilkan kembali tutup kepala (tengkuluk) dalam kesehariannya ditengah-tengah masyarakat sama dengan membangkitkan batang yang terendam dan mengait barang yang teranyut. (Nurlaini, 2017:11)

Melihat sejarah budaya masyarakat Jambi yang begitu beragam, maka pengetahuan tentang tutup kepala/tengkuluk daerah Jambi, dan teknik-teknik 
pemakaiannya, sangat memegang peranan di dalam kehidupan sejarah budaya masyarakat Jambi. Perputaran waktu dari zaman ke zaman, serta pengaruh dari interaksi budaya luar telah menerpa pemakaian tutup kepala dalam kehidupan sehari-hari.

Ketika masuknya pengaruh Islam di tanah Jambi pada abad ke 13 Masehi, tengkuluk bukan hanya sebagai bagian dari penutup tubuh tapi merupakan bagian dari penutup aurat sesuai dengan falsafah adat Jambi "adat bersendi syara', syara' bersendi Kitabullah." dan diterjemahkan dalam seloko adat " "syarak mengato, adat memakai." Dimana dalam tata pergaulan hidup bermasyarakat disesuaikan dengan peraturan Islam.

Oleh karena itu menarik melihat kembali bagaimana estetika tengkuluk sebagai pakaian perempuan Jambi dengan identitas perempuan Melayunya. Keragaman dan ciri khas tengkuluk yang cukup banyak, menarik untuk dikaji lebih jauh agar kita bisa mengenal dan melestarikan tengkuluk sebagai warisan budaya kita yaitu budaya melayu Jambi.

\section{Penelitian Relevan}

Penelitian mengenai kajian melayu sudah banyak yang melakukan, tetapi kajian-kajian yang telah ada masih bersifat umum. Bahasan mengenai fokus budaya melayu Jambi masih sedikit peneliti yang mengkajinya. Beberapa tulisan seperti Anggia Maresa, "Estetika Simbolis Dalam Busana Pengantin Adat Minangkabau di Padang" dalam jurnal Filsafat UGM, Vol 19,No. 3 tahun 2009. Dalam jurnal ini mengkaji mengenai busana menjadi ukuran dari kualitas martabat dan kesopanan pemakainya. Desain atau pola dalam busana itu mengandung nilai keserasian dan keindahan. Perkembangan rasa estetika manusia kemudian menyebabkan perkembangan busana yang beraneka ragam. Dalam adat Minangkabau, busana berkembang berdasarkan pandangan hidup yang terjadi karena kemampuan masyarakat berpikir.

Buku edisi pertama "Kuluk: penutup kepala warisan leluhur dari Jambi" (Aswar, 2010) memaparkan salah satu kekayaan budaya masyarakat melayu Jambi yaitu kebiasaan para perempuan melayu Jambi menggunakan penutup kepala atau yang disebut juga tengkuluk/kuluk yang digagasankan oleh ibu Ratu Munawwaroh Zulkifli Nurdin bertujuan untuk mendokumentasikan kuluk/tengkuluk khas Jambi, selain itu juga bertujuan agar masyarakat mengetahui adanya salah satu kekayaan budaya ini dan masyarakat turut melestarikannya, anata lain mengenakannya dalam banyak kesempatan.

Edisi ke II buku "Tekuluk penutup kepala warisan luhur dari Jambi" yang digagas oleh ketua dekranasda provinsi Jambi (Hj. Yusniana Hasan Basri Agus) mengemukakan fakta-fakta lain mengenai hubungan nilai-nilai budaya antara satu kabupaten dengan kawasan lainnya. Melalui buku edisi II, diharapkan tekuluk sebagai warisan luhur dari Jambi dapat dijadikan sebagai langkah nyata dari perwujudan gagasan besar dalam usaha membina dan mengembangkan nilai-nilai budaya yang ada pada masing-masing kabupaten kota yang mencermikan nilai-nilai luhur Jambi sesuai dengan kandungan falsafah dan dasar negara serta kepribadian bangsa.

Pada buku edisi III "Tekuluk: Penutup Kepala Warisan Luhur dari Jambi" yang diterbitkan oleh Dekranasda Provinsi Jambi 2017 dengan ketua pembina ibu Hj. Sherrin Tharia Zola. Buku ini, mengekspresikan adat yang ia anut sebagai cerminan masyarakat Jambi yang kini sedang berada di jalan transisi memasuki era global. Adat Jambi yang sifatnya "kenyal" terbuka bagi masyarakat pada umumnya tidak hanya teruntuk bagi masyarakat Jambi saja. Ia dapat pula mengayomi masyarakat selain masyarakat Jambi yang memerlukan naungannya dengan syarat yang bersangkutan ikut ketentuan tata nilai yang dikandung adat sesuai bidang yang dikehendaki. Melalui buku ini memahami dan menghayati keanekaragaman fungsi, makna, arti dan cara pemakaian tekuluk yang dilengkapi dengan busana, kain dan aksesoris yang tersebar di provinsi Jambi di 10 kabupaten kota.

Lindayanti dkk, dalam buku "Jambi dalam sejarah 1500-1942". Cakupan tulisan yang cukup panjang dalam penelitian ini untuk dapat menelusuri dinamika Jambi sejak masuknya anasir luar dari timur tengah, anak benua asia (India) dan Eropa. Pengaruh anasir Eropa yang menonjol adalah Belanda yang kemudian menjadi penguasa bumi nusantara termasuk Jambi.

Pada penelitian ini penulis ingin memaparkan salah satu warisan ragam nilai-nilai budaya melayu Jambi, melalui salah satu tradisi pakain penutup kepala perempuan melayu Jambi dalam estetika pemakaian tengkuluk yang penuh akan konsep filosofi adat dan konsep islam. Sebagai mana tercermin dalam seloko adat melayu Jambi yaitu Adat Bersendikan Syara', Syara' Bersendikan Kibullah. Syara' Mengato, Adat Memakai."

\section{Teori Interaksional Simbolik}

Teori interaksi simbolik memandang bahwa kehidupan sosial merupakan suatu proses interaksi yang membangun, memelihara serta mengubah kebiasaan tertentu, selain itu makna dapat berubah dari waktu ke waktu, dari konteks ke konteks, serta dari kelompok sosial ke kelompok sosial lainnya.

Pada penelitian ini, pendekatan interaksi simbolik digunaka untuk memaparkan bagaimana dan pemahaman tradisi pakaian tradisional tengkuluk masyarakat melayu Jambi sebagai salahsatu simbol pakaian budaya melayu Jambi. Pada penelitian ini yang menjadi fokus interaksi simboliknya adalah efeek interpretasi terhadap wanita melayu Jambi yang sedang diinterpretasikan. Proses pemaknaan kreativitas estetika tengkuluk dan cara memakainya dengan pakaian tradisional dalam implementasi kreativitas berbasis 
tradisi mayarakat itu sendiri. Terkait dengan pernyataan tersebut, interaksi simbolik memahami manusia bahwa berdasarkan pandangan subjek itu sendiri. Artinya subjeklah yang menentukan kondisinya subjeklah yang menentukan kondisinya serta lingkungan mereka berdasarkan simbol-simbol yang dimilikinya dan mereka sendirilah yang menjelaskan serta menentukan prilaku bukan orang di luar dari diri.

\section{METODE}

Metode yang digunakan dalam penelitian ini adalah metode penelitian kualitatif deskriftif dengan pendekatan interaksi simbolik. Menurut David Williams (1995) pendekatan metode kualitatif merupakan metode pengumpulan data pada suatu latar alamiah, dengan menggunakan metode alamiah dan dilakukan oleh peneliti yang tertarik secara alamiah. Sedangkan Denzin \& Lincol (1987) menyatakan bahawa penelitian kualitatif merupakan penelitian yang menggunakan latar ilmiah, dengan maksud menafsirkan aktivitas yang terjadi dan dilakukan dengan jalan melibatkan berbagai metode yang ada.

Sementara, menurut Jane Richie penelitian kualitatif adalah upaya penelitian kualitatif adalah upaya untuk menyajikan dunia sosial, dan perspektifnya didalam dunia, dari segi konsep, perilaku, persepsi dan persoalan tentang manusia yang diteliti (Moleong, 2006:6). Sedangkan Moleong (2006) sendiri mensintesakan beberapa definisi penelitian kualitatif bahwa penelitian kualitatif adalah penelitian yang bermaksud untuk memahami fenomena tentang apa yang dialami oleh subjek penelitian, misalnya perilaku, motivasi, tindakan dan lain-lain secara holistik dan dengan cara deskrpsi dalam bentuk kata-kata dan bahasa, pada suatu konteks khusus yang alamiah dan dengan memanfaatkan berbagai metode alamiah.

Pada pendekatan interaksi simbolik digunakan untuk menjelaskan bagaimana pemaknaan dan pemahaman penutup kepala tengkuluk sebagai simbol implementasi kreativitas berbasis tradisi bagi masyarakat melayu Jambi. Salah satu yang menjadi fokus interaksi simbolik adalah efek interpretasi terhadap orang yang tindakannya yang diinterpretasikan. Tengkuluk merupakan simbol kreativitas yang berbasis tradisi, diimplementasi karena hasil kesepakatan bersama dalam masyarakat melayu Jambi. Selain itu, terkait dengan pernyataan para ahli bahwa interaksi simbolik memahami manusia berdasarkan pandangan subjek itu sendiri, yang aartinya subjeklah yang menentukan kondisinya serta lingkungan mereka berdasarkan simbolsimbol yang mereka miliki dan mereka sendirilah yang menjelaskan dan menentukan perilaku mereka, bukan orang diluar dari diri mereka.

Guna melengkapi data tertulis, penulis juga melakukan wawancara yang mendalam, yang dilakukan secara pribadi agar informan dapat memberikan informasi secara terbuka dan lebih nyaman, sehingga bisa mengungatkan data tertulis yang ada, agar dapat diinterpretasikan dengan benar.

\section{Subjek Penelitian}

Berdasarkan sifat penelitian kualitatif, informasi diperoleh tidak hanya dari manusia tetapi juga termasuk peristiwa dan situasi yang diobservasi dalam penelitian ini. Dalam hal ini, informan diharapkan akan memberikan data primer yang berkaitan langsung dengan penelitian. Menurut Kunto, dalam teknik penelitian kualitatif ada tiga tahapan yaitu: 1) Pemilihan sample awal, apakah informan untuk diwawancarai atau situasi sosial untuk diobservasi yang terkait dengan fokus penelitian. 2) Pemilihan sample lanjutan untuk memperluas deskripsi informasi dan memperoleh variasi. 3) Menghentikan sampel lanjutan bila variasi informasi tidak ditemukan lagi (Bungin, 2003: 53-54).

Subjek yang dimaksud pada penelitian ini adalah masyarakat melayu Jambi, tepatnya masyarakat kota Jambi dan beberapa pakar yang berkaitan dengan tengkuluk.

\section{Objek Penelitian}

Yang menjadi objek utama dalam penelitian ini adalah budaya melayu Jambi dalam pakaian tradisional tengkuluk sebagai penutup kepala. Selain itu objek penelitian ini juga menyangkut aspek-aspek sejarah dan tradisi yang dilakukan oleh pengguna tradisi pakaian tengkuluk sebagai penutup kepala, baik itu simbol verbal maupun non verbal yang digunakan oleh pengguna tengkuluk, dalam hal ini masyarakat kota Jambi.

\section{HASIL DAN PEMBAHASAN \\ Tengkuluk Sebagai Pakaian Tradisional Melayu Jambi}

Tengkuluk atau kuluk merupakan penutup kepala warisan budaya tradisional perempuan melayu Jambi yang sudah mulai ditinggalkan, namun saat ini pemerintah bersama masyarakat melayu Jambi kembali mengeliatkan tradisi berbusana yang telah diwariskan oleh leluhurnya.

Menelusuri tradisi berbusana sebagaimana yang telah dipakai oleh masyarakat Melayu Jambi sekarang, diduga bermula dari pengaruh kebudayaan Dongson. Kebudayaan Dongson merupakan kebudayaan yang berasal dari Vietnam yang ada pada masa dinasti Han yaitu di zaman perunggu memberikan pengaruhnya ke Asia Tenggara sampai ke Indonesia. Pengaruh tersebut berawal dari kegiatan bertani, menangkap ikan di laut, berlayar dan memancing. Tradisi mereka berpakaian terutama pakaian wanita sangat mempengaruhi tradisi berpakaian suku-suku di Provinsi Jambi. Pengaruh ini tampak dari seratus macam tradisi penutup kepala atau tengkuluk yang tersebar diseluruh daerah yang ada di Jambi. Bentuk dan cara pemakaian yang beraneka ragam dari tengkuluk tersebut disesuaikan dengan penggunaannya dalam kegiatan sehari-hari. (UKM Riset \& Penalaran EXIST, 2014) Namun pernyataan ini 
dibantah oleh kepala museum Jambi Ibu Nurlaini, "tekuluk/tengkuluk sudah ada pada zaman melayu tua, sementara Vietnam masuk pada zaman melayu muda. Dimana ada kerajaan melayu maka di sana ada kebudayaan tengkuluk. Seperti kebudayaan India, Kuba dan China." (wawancara, Jambi, 28 Agustus 2019). Lebih lanjut Nurlaini menjelaskan bahwa pada awalnya tengkuluk yg dipakai oleh kaum wanita melayu Jambi merupakan jenis kain sarung berukuran 1 eto (pendek) yang dipakai untuk kegiatan sehari-hari oleh para petani wanita melayu Jambi pergi ke umo / ladang / sawah.

Pada tahun 1452 mulai tampak pengaruh Islam yang dibawa oleh Datuk Paduko Berhalo seorang Ulama Asia, bekas Panglima Tentara Turki yang menetap di Muara Sabak, konon ceritanya menikah dengan putri raja Jambi yang bernama Putri Selaras Pinang Masak Putri, yang memegang teguh pada yang memegang teguh pada prisip"Tiga Tungku Sajarangan" yang dimaksud dengan hal tersebut yaitu "Adat Bersendi Syara', Syara' Bersendi Kitabullah." Makna yang terkandung di dalamnya adalah Syara' (ayat) mengatakan Habluminallah. Adat memakai Habluminannas. Prinsip dalam falafah kehidupan ini memperlihatkan dan menjelaskan, tidak adanya pertentangan antara agama dengan adat pada sejak saat agama Islam masuk (Aswar, Sativa Sutan, 2010:7).

Pendapat lain, mengatakan bahwa keberadaan tengkuluk diketahui sudah ada sejak jaman kerajaan Melayu, yakni pada sebuah kerajaan yang terletak di pulau Sumatra sekitar abad ke-7. Pada masa tersebut, tengkuluk digunakan oleh kaum ibu-ibu dalam berbagai kegiatan dan kesempatan. (Putu Elmira, 2018)

Tradisi penutup kepala atau tengkuluk sudah ada sebelum masyarakat Jambi mengenal agama Islam. Pada masa itu tengkuluk hanya sebagai aksesoris atau hiasan kepala sebagai suatu keindahan perempuan-perempuan melayu Jambi, yang digunakan sebagai penutup kepala pada saat pesta, atau hari-hari besar. Tengkuluk juga dijadikan sebagai penahan kepala dari beban beban ketikan meletakan barang bawaan di atas kepala atau pun berfungsi sebagai pelindung kepala dari teriknya sengat matahari ketika perempuan melayu pergi berladang atau berumo pada saat itu. Tengkuluk dan baju kurung hanya sebagai penutup tubuh dan aksesoris. Namun setelah masuknya agama Islam di tanah melayu kebiasaan menggunakan baju kurung dan penutup kepala tengkuluk dapat diartikan sebagai bentuk ketaatan dalam menjalankan agama Islam. Adat dan agama bersatu padu membentuk suatu keharmonisan dalam kehidupan masyarakat. Sesuai dengan seloko adat melayu Jambi "adat bersendi syarak, syarak bersendi kitabullah. Syarak mengato, adat memakai." Ketika agama Islam sudah berkembang di tanah melayu, baju kurung dan tengkuluk menjadi satu kepaduan yang berfungsi bukan hanya sekadar sebagai penutup kepala atau pembungkus tubuh, namun sudah keharusan sebagai penutup aurat perempuan sesuai dengan syariat Islam yang berkembang di tanah melayu.
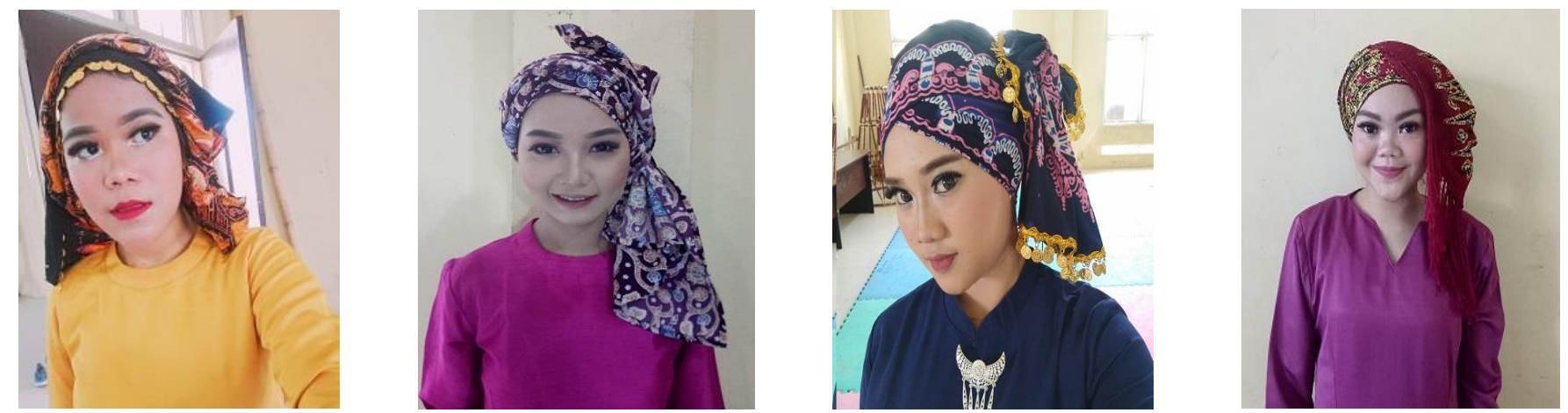

Keterangan: contoh ragam model tengkuluk sebagai penutup kepala / sebagai hiasan kepala perempuan melayu Jambi. (Dok. Pribadi)
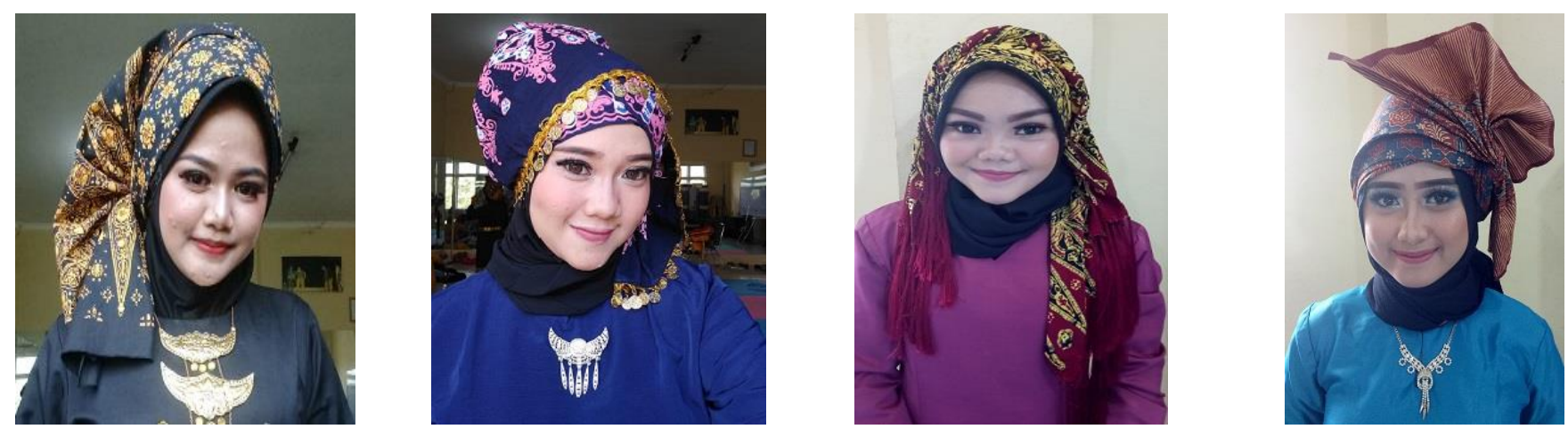

Keterangan: contoh tengkuluk bukan hanya sebagai penutup kepala namun juga sebagai penutup aurat perempuan melayu Jambi. (Dok. Pribadi) 


\section{Estetika Ragam Tengkuluk Pakaian Tradisional Melayu Jambi}

Estetika merupakan salah satu cabang filsafat yang membahas keindahan. Estetika adalah suatu ilmu yang membahas tentang bagaimana keindahan bisa terbentuk dan bagaimana agar dapat merasakannya juga. Lebih lanjut pembahasan mengenai estetika merupakan sebuah filosofi yang mempelajari nilai-nilai sensoris yang kadang dianggap sebagai penilaian terhadap sentimen dan rasa. Dengan Estetika merupakan cabang ilmu yang sangat dekat dengan filosofi seni. (Wikipedia, Estetika, 2019)

Estetika dalam pakaian tengkuluk/ tekuluk, merupakan konsep yang dibentuk oleh masyarakat yang melahirkan bentuk-bentuk tengkuluk/tekuluk yang berdasarkan adat dan syariat Islam untuk menutup aurat.

Estetika dalam pemakaian tengkuluk terdiri dari dua konsep yaitu konsep adat dan konsep islam. Sebelum lahirnya Islam, konsep yang dikenal oleh masyarakat melayu adalah konsep adat. Hal ini dikarenakan konsep adat dan budayalah yang lahir terlebih dahulu dalam masyarakat melayu sebelum adanya Islam. sehingga estetika pemakaian tengkuluk hanya berdasarkan konsep adat saja. Namun ketika masuknya Islam di tanah melayu maka estetika pemakaian tengkuluk/kuluk menggunakan konsep Islam berlandaskan syariat "adat bersendikan syara', syara' bersendikan kitabullah. Adat mengato, syara' memakai."

Dalam pemakaian ragam tengkuluk sebagai warisan budaya melayu tak terlepas dari estetika dan artistika. Jika estetika merupakan konsep yang dibentuk oleh masyarakat yang melahirkan bentuk-bentuk tengkuluk. Maka artistika merupakan suatu keindahan yang tampak atau yang terlihat. Dalam hal ini terlihat dalam berbagai macam tengkuluk. Menurut Nurlaini, dari estetika ada 7859 ragam koleksi tengkuluk di seluruh tanah melayu Jambi dan baru $10 \%$ yang telah terpublikasi.

Ragam tutup kepala berasal dari kata ragam berarti macam-macam, tutup berarti melindungi, kepala adalah bagian yang tertinggi dalam badan manusia berbagai bangsa di dunia, yang sakral yang terpening dari seluruh tubuh. Kepala juga merupakan tempat masuknya roh atau sukma manusia, oleh karena itu kepala perlu dihias dan dipelihara. Ragam tutup kepala berarti adalah bermacam-macam pelindung kepala yang bagian tertingginyadalam tubuh manusia. (Nurlaini, 2017:18).

Lebih lanjut Nurlaini mengatakan, bahwa berbeda dengan budaya-budaya lain yang mengenal tutup kepala tekuluk ini. Tehnik mengikat dan menyisipkan tengkuluk/kuluk Melayu ini tidak dimiliki oleh suku dan budaya lain.

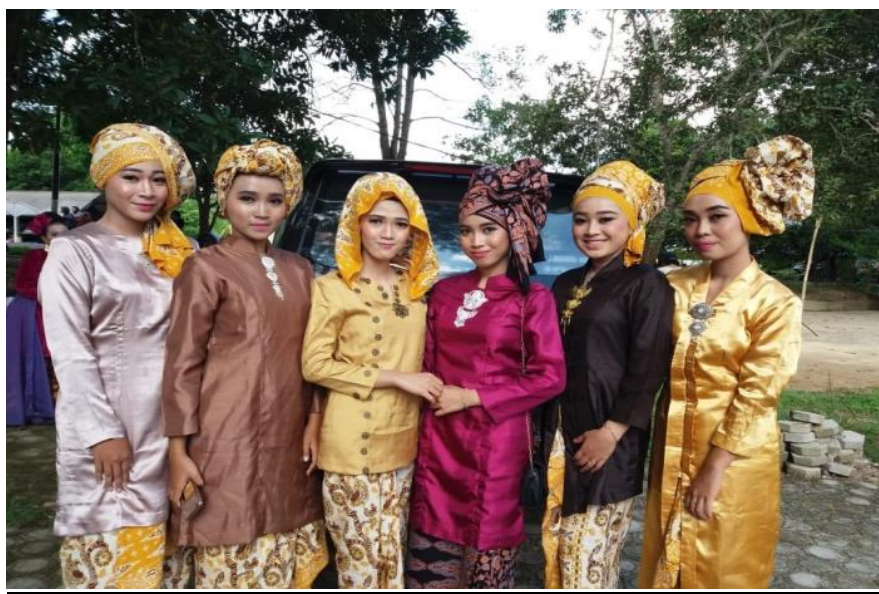

Keterangan: estetika dan artistika ragam tengkuluk Melayu Jambi dalam konsep adat. (Dok. Pribadi)

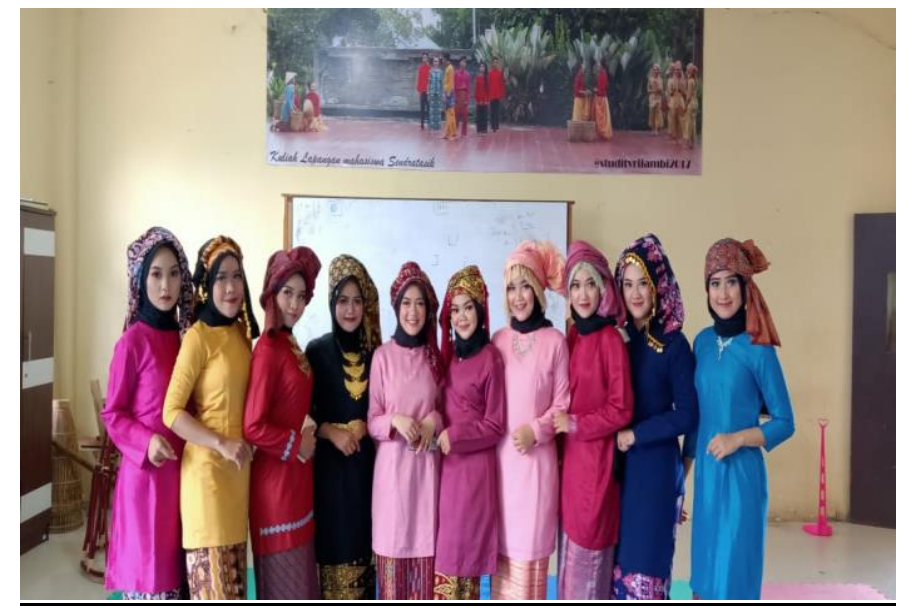

Keterangan: estetika dan artistika ragam tengkuluk melayu Jambi dalam konsep Islam. (Dok. Pribadi)

Setelah masuknya agama Islam di tanah melayu Jambi, masyarakat melayu Jambi terkenal dengan budaya dan keyakinan yang kuat pada ajaran agama Islam. Sehingga antara adat dan ajaran Islam dalam kehidupan masyarakat Jambi selalu sejalan dengan pedoman hidupnya. Hal tersebut dalam seloko ada yang menjadi pedoman yaitu "adat bersendi syara', syara" bersendi kitabbullah" yang berarti yang semula berawal dari "adat bersendi layak dan patut". Kini layak dan patut adalah dalam ukuran simbolnya berdasarkan ketentuan agama Islam yaitu Syara' dan Kitabbullah.(Nurlaili, 2017: 19).

Pakaian adat perempuan melayu Jambi sesuai dengan agama yang mereka anut, umumnya perempuan dewasa melayu Jambi menutup aurat. Kepala dan rambut merupakan salah satu aurat kaum perempuan dan rambut sebagai mahkota perempuan tidak boleh terurai begitu saja. Oleh karena itu, umumnya bagi masyarakat Jambi antara pakaian dan tutup kepala merupakan satu kesatuan yang saling berhubungan yang menjadikan simbol kepatutan dalam berbusana perempuan melayu Jambi.

Tengkuluk merupakan salah satu pelengkap adat dalam tradisi berbusana yang harus digunakan baik 
untuk keperluan sehari-hari maupun untuk keperluan acara khusus. Pada setiap model tengkuluk/kuluk, terkandung falsafah yang memiliki makna nilai atau norma yang menentukan bagaimana kita harus bersikap, bertindak dan berperilaku, juga memberikan aturan untuk kita (Sativa Sultan Aswar, kuluk, 2010:9). Menurut Nurlaili, tutup kepala adalah produk adat dan budaya yang mengungkapkan aspek kehidupan masyarakat melayu. Penutup kepala dan pakaian merupakan simbol atau lambang yang memiliki makna, simbol maupun wibawa serta cerminan kepribadian masyarakat danalam pikiran masyarakat setempat tersebut. Lebih lanjut Nurlaili memberikan contoh, penutup kepala wanita suku Melayu Jambi yang penggunaan ujung kainnya terjuntai di sebelah kanan menandakan bahwa si wanita telah menikah dan jika ujung kainnya jatuh ke sebelah kiri berarti si wanita masih dapat dilamar yang berarti single (wawancara Nurlaili, Rabu, 28 Agustus 2019). Masih menurut Sativa, uniknya tengkuluk yang mereka gunakan untuk mengaji maupun berzikir, kedua tengkuluk ini ditambah dengan tengkuluk untuk pergi ke sawah dan keladang digunakan diseluruh provinsi Jambi.

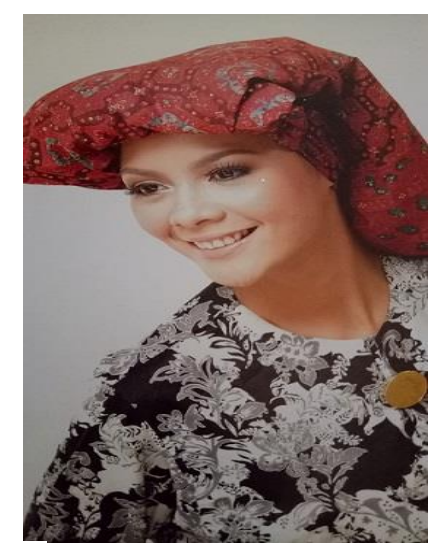

Keterangan: salah satu contoh tengkuluk umumnya yang digunakan wanita melayu Jambi untuk kegiatan sehari-hari ke umo/ladang/sawah. Dok. Buku "Kuluk penutup kepala warisan luhur dari Jambi” oleh Sativa Sultan Aswar, 2010: 11)

Inventarisasi pemakaian penutup kepala tengkuluk ini ditemukan beragam estetika dan artistika dalam masyarakat perempuan melayu Jambi. Meskipun terdapat berbagai perbedaan bentuk dan makna dari berbagai daerah di tanah melayu Jambi, namun juga terlihat adanya persamaan. Misalnya, tengkuluk ke umo/sawah/ladang hampir semuanya sama pada setiap daerah di Jambi.

Keunikan Tengkuluk di daerah Jambi terletak pada cara pemakaiannya yaitu tidak menggunakan peniti atau jarum bentul sebagai pengguat dalam penggunaannya tetapi hanya menggunakan keterampilan dalam mengikat dan menyisipkan kain. Hal ini berkaitan dengan filosofi adat. Menurut kepala museum Nurlaini “ filosofi tengkuluk itu terletak dari seni mengikat kain tersebut, semakin kencang kita mengikat maka semakin tinggi keyakinan kita pada Sang Khalik/pencipta." (wawancara, Rabu, 28 Agustus 2019).

Sebagai masyarakat yang mayoritas beragama Islam, menurut Sitiva (2010:9) maka Jambi dapat menjadi pionir dan contoh bagi jati diri bangsa Indonesia yang tidak ada dimiliki oleh bangsa lain yang mayoritas beragama Islam.

Pada tiap ikatan terdapat ragam estetika maupun artistika yang memiliki simbol makna dan falsafah adat budaya masyarakat melayu dengan religinya.

\section{Pengaruh Mordenitas terhadap Warisan Budaya Tengkuluk Perempuan Melayu Jambi}

Dengan berkembangnya zaman maka berkembang pula pemikiran manusia. Karena perkembangan masyarakat bertautan erat dengan perkembangan cara berpikir manusia yang mempengaruhi pola kehidupan manusia termasuk di dalamnya keadaan alam, adat istiadat, kebudayaan, kepercayaan, ekonomi, politik dan sosial. Karena faktor-faktor tersebut maka lahir dan terbentuklah berbagai suku bangsa di Indonesia dengan beragam bentuk kebudayaan, adat istiadat, suku dan ras yang cukup menonjol.

Karena perkembangan zaman tersebut, maka tidak bisa dipungkiri antara budaya yang satu dan yang lainnya akan saling mempengaruhi, termasuk didalamnya cara kita berpakaian dalam kehidupan sehari-hari. Perkembangan zaman banyak memperngaruh gaya berpakaian masyarakat melayu Jambi namun juga tidak meninggalkan ciri khas dari busana orang melayu tersebut. Begitu juga dengan penutup kepala tengkuluk/kuluk yang menjadi ciri khas masyarakat melayu Jambi.

Pada awalnya tengkuluk melayu Jambi hanya dikenal 1 eto yang merupakan pakaian penutup kepala sehari-hari untuk pergi ke ladang/umo/sawah/talang saja. Namun dengan berkembangnya zaman masyarakat melayu juga mulai mengkreasikan tengkuluk 2 eto untuk kegiatan menari dan 3 eto untuk kegiatan adat. Namun yang menjadi ciri khasnya tidak hilang yaitu filosofi dalam mengikat tengkuluk. Ragam-ragam tengkuluk ini terus belanjut dalam budaya masyarakat melayu Jambi sampai masuknya pengaruh Islam.

Setiap ikatan dan bentuk ragam estetika dari tengkuluk melayu Jambi memiliki simbol makna dan falsafah adat dan religi yang berkembang dalam masyarakat melayu dari generasi ke generasi.

Menurut duta tengkuluk provinsi Jambi, Siti Arafah mengemukakan, "modernisasi tengkuluk tidak dapat merubah estetika dari tengkuluk tersebut. Bentuk dan model tengkuluk sudah ada dari zaman dahulu. Kita tidak dapat merubahnya sembarangan, seperti yang kita mau. Tapi kita bisa memodernkannya dengan bantuan make up dan pakaian yang dipakai. Karna tengkuluk bisa dikreasikan dengan pakaian apa saja tetap sesuai." (wawancara, Rabu, 28 Agustus 2019) 
Selaras dengan pernyataan Siti Arafah, Nurlaili Juga menegaskan terkait dengan pengaruh mordenitas terhadap warisan budaya tengkuluk melayu Jambi mengemukakan bahwa tidak bisa dengan sembarangan mengubah estetika dari tengkuluk. Dikarenakan tiap ikatan dan ragam tengkuluk tersebut memiliki simbol dan makna dan filosofi. Namun bukan berarti kita tidak bisa mengikuti perkembangan zaman, kita bisa memoderenisasikannya melalui pakaian, kain bawahan yang digunakan, baju kurung, model kain, bahan tengkuluk, perwanaan maupun ukuran kain/selendang. Kalau dahulu hanya menggunakan kain sarung atau selendang batik, sekarang bisa digunakan dengan bahan songket. Serta bisa digunakan dengan hijab.(wawancara, Rabu 28 Agustus 2019).

Di era modern ragam tengkuluk bisa disesuaikan dengan pakaian yang modern tidak hanya dengan baju kurung saja. Begitu juga dengan motif dan pilihan kain/selendang yang digunakan. Pemakaian kain batik dan songket untuk bahan tengkuluk menjadikan tengkuluk sebagai warisan budaya yang istimewa hingga kini. Tengkuluk di era modern menurut Susilawati (Kasi Industri Kimia, Agro dan Hasil Hutan Disperindag Kota Jambi) "harus dipertahankan karena tengkuluk merupakan salah satu warisan budaya kearifan lokal yang harus tetap dikembangkan di Jambi, agar tidak hilang dimakan waktu dengan banyaknya muncul dan masuknya budaya luar di Jambi." (wawancara, Sabtu 14 September 2019)

Lebih lanjut Susilawati mengemukakan dengan membumikan kembali tradisi pemakaian tengkuluk di Era modern ini, akan sangat membantu mendongkrak perekonomian rakyat. Melalui bahan yang digunakan untuk pemakaian kain dan selendang untuk tengkuluk yang digunakan. Maka akan banyaknya permitaan dan pembelian batik dan songket Jambi dan akan memberi keuntungan bagi para UMKM pengrajin batik dan songket di Jambi.

Ada banyak dampak positif dari melestarikan pakaian tradisional tengkuluk bagi perempuan melayu Jambi, salah satunya adalah bisa membantu meningkatkan perekonomian rakyat melalui UMKM batik dan songket serta beriring dapat melastrikan dan memperkenalkan kain batik dan songket Jambi dikancah nasional maupun internasional. Selain itu, melalui tengkuluk kita dapat menjaga ragam warisan budaya dan mempertahankan simbol dan nilai-nilai filosofi yang ada.

Ada tiga batas tindakan menurut Thomas Aquinus, yaitu:

\section{Keseimbangan;}

keseimbangan dalam hal ini dilihat dari cara pakai tengkuluk yang disesuaikan dengan postur tubuh dan bentuk wajah.

\section{Kecemerlangan;}

Kecemerlangan yang dimaksud adalah perpaduan warna yang digunakan dalam pemakaian busana melayu dan tengkuluk. Contoh, warna merah dipadukan dengan warna hitam, biru dengan warna pink dan warna kuning dengan putih atau silver dll.

\section{Kesempurnaan tanpa cela;}

Kesempurnaan tanpa cela yang dimaksud adalah tidak ada cacat dilihat orang dari segi pemakaian, sehingga yang terlihat adalah kesempurnaan.
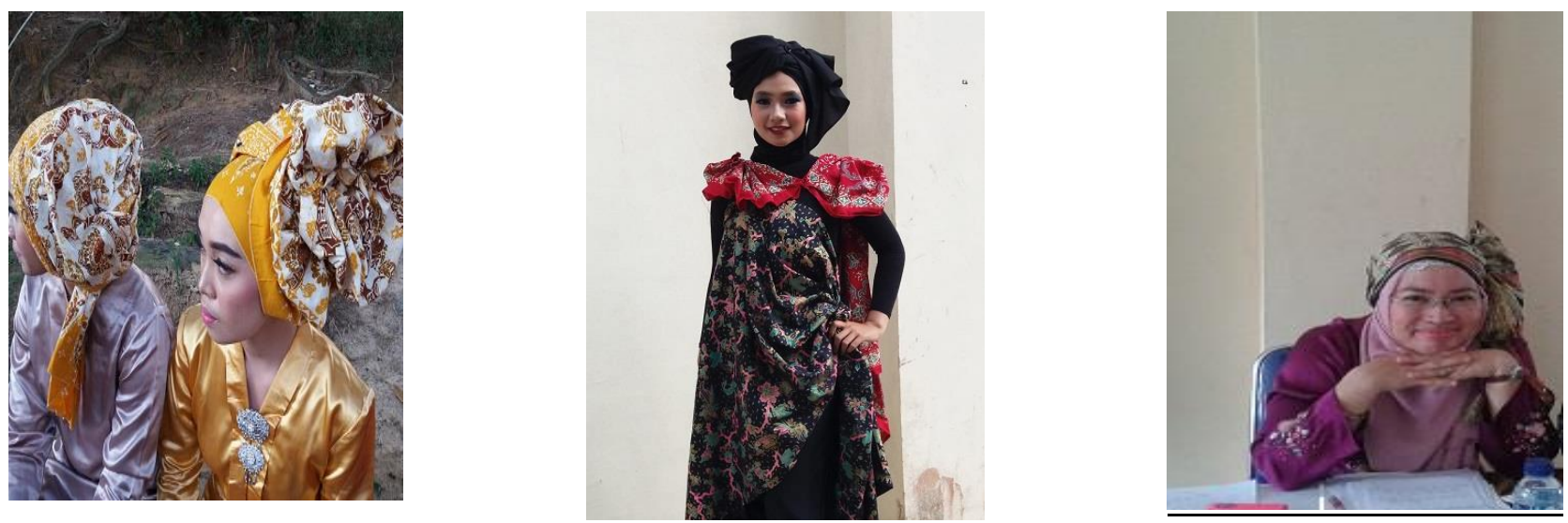

Keterangan: salah satu contoh pengaruh mordenitas tengkuluk sebagai warisan budaya masyarakat melayu kota Jambi. (Dok. Pribadi)

Dengan demikian dapat disimpulkan bahwa kita tidak bisa sembarangan membuat estetika tengkuluk karena setiap ikatan, bentuk, warna dan estetikanya memiliki simbol dan makna secara filosofi dalam adat dan budaya dari generasi terdahulu.

\section{Fungsi dan guna tengkuluk bagi perempuan melayu Jambi}

Pengertian fungsi menurut Bahar (2009: 241)terkandung suatu makna utama (kunci) yaitu 'sumbangan' (contribution) yang diberikan oleh sesuatu untuk sesuatu. Maka tengkuluk penutup kepala perempuan melayu Jambi memiliki fungsi sebagai beriku:

1. Sebagai identitas jatidiri perempuan melayu Jambi.

Tiap daerah akan memiliki bentuk dan ciri khas sendiri sesuai denga filosofi daerah tersebut. Menurut 
datuk Al Basri Azra'i (ketua Lembaga Adat Melayu Kota Jambi) tengkuluk memiliki nilai filosfi jati diri wanita melayu Jambi, hal ini bisa filihat dari estika tengkuluk tersebut bisa menentukan status atau kelas si pemakai tengkuluk tersebut. Baik dari status sosial maupun status ekonomi pemakai. (wawancara, Jambi, 16 oktober 2019).

2. Sebagai identitas jatidiri muslimah melayu Jambi.
Tengkuluk sebagai mahkota membantu menutup rambut wanita yang merupakan aurat bagi muslimah.

Sementara kegunaan tengkuluk bagi perempuan melayu Jambi adalah sebagai berikut:

1. Pelindung kepala dari matahari.

2. Pelingung kepala /penahan dari beban yang dibawa perempuan di atas kepalanya.

3. Sebagai keindahan mahkota wanita melayu.
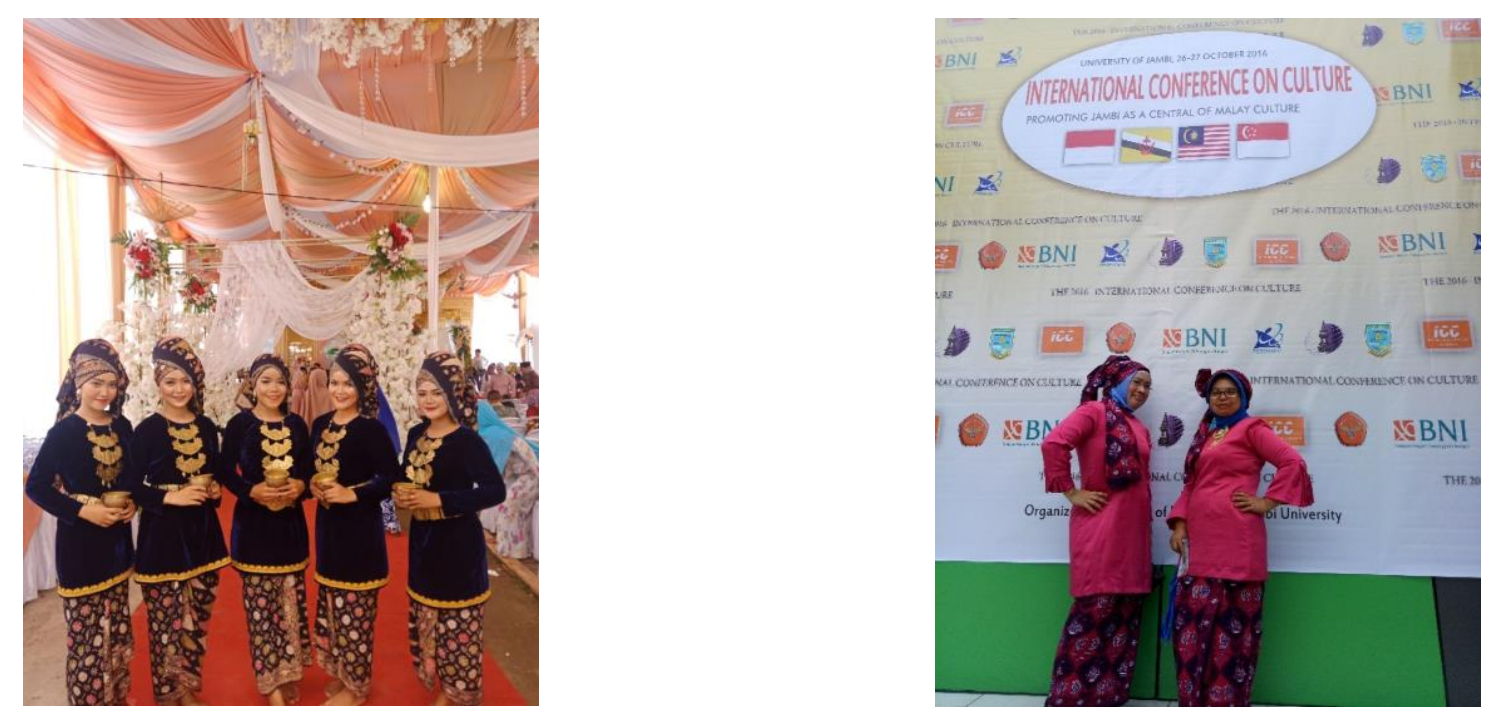

Keterangan: keindahan tengkuluk melayu Jambi dengan batik dan baju kurung melayu Jambi. (Dok. Pribadi)

\section{SIMPULAN}

Tengkuluk merupakan identitas jatidiri perempuan melayu. Tradisi penutup kepala atau tengkuluk sudah ada sebelum masyarakat Jambi mengenal agama Islam. Pada masa itu tengkuluk hanya sebagai aksesoris atau hiasan kepala sebagai suatu keindahan perempuanperempuan melayu Jambi, yang digunakan sebagai penutup kepala pada saat pesta, atau hari-hari besar. Tengkuluk juga dijadikan sebagai penahan kepala dari beban beban ketikan meletakan barang bawaan di atas kepala atau sebagai pelindung kepala dari teriknya sengat matahari ketika perempuan melayu pergi berladang atau berumo pada saat itu. Tengkuluk dan baju kurung hanya sebagai penutup tubuh dan aksesoris. Namun setelah masuknya agama Islam di tanah melayu kebiasaan menggunakan baju kurung dan penutup kepala tengkuluk dapat diartikan sebagai bentuk ketaatan dalam menjalankan agama Islam. Adat dan agama bersatu padu membentuk suatu keharmonisan dalam kehidupan masyarakat. Sesuai dengan seloko adat melayu Jambi "adat bersendi syarak, syarak bersendi kitabullah. Syarak mengato, adat memakai." Ketika Islam sudah berkembang di tanah melayu, baju kurung dan tengkuluk menjadi satu kepaduan yang berfungsi bukan hanya sekadar sebagai penutup kepala atau pembungkus tubuh, namun sudah keharusan sebagai identitas jatidiri muslimah melayu, tengkuluk menjadi bagian penutup aurat perempuan sesuai dengan syariat Islam yang berkembang di tanah melayu.

\section{DAFTAR PUSTAKA}

Aswar, Sativa Sultan. 2010.Kuluk Penutup Kepala Warisan Luhur Dari Jambi. Edisi I. Jakarta: Dian Rakyat.

Bahar, Mahdi. 2009. Musik Perunggu Nusantara. Bandung: Sunan Ambu STSI Press.

Denzin, Norman K., Lincoln, Yvonna S., (ed). (1994). Handbook of Qualitative Recearch. New Delhi, India: Sage Publications, Inc.

Dwi, Ratna Nurhajarini. 2005. Kain Kebaya dan Rok Pakaian Perempuan Yogyakarta Pada Awal Abad ke-20. Yogyakarta: LKiS..

Lindayanti dkk. 2013. Jambi dalam Sejarah 1500-1942. Jambi: Dinas Kebudayaan dan Pariwisata Provinsi Jambi

Lembaga Adat Provinsi Jambi. 2001. Lembaga Adat Provinsi Jambi. Jambi: Lembaga Adat Provinsi Jambi.

Lembaga Adat Provinsi Jambi. 2003. Dinamika Adat Jambi Dalam Era Global. Jambi: Lembaga Adat Provinsi Jambi.

Moloeng, J. Lexy. (2000). Metode Penelitian Kualitatif. Bandung: Remaja Rosdakarya.

Nurlaini. 2017. Tekuluk: Penutup Kepala Warisan Luhur dari Jambi. Edisi III. Jambi: Dekranasda Provinsi Jambi.

Putu Elmira, 2018, https://www. Liputan6.com/lifestyle/mengenal-tengkulukpenutup-kepala-khas-perempuan-jambi. (diakses tanggal 23 Juli 2019) 
Somad, Kemas Arsad. 2002. Mengenal Adat Jambi Dalam Perspektif Modern. Jambi: Dinas Pendidikan Provinsi Jambi.

Tim Dekranasda. 2013. Tekuluk Penutup Kepala Warisan Luhur Dari Jambi. Edisi II. Jakarta: Dian Rakyat.

UKM Riset \& Penalaran EXIST, 2014, https://www.facebook.com/ukmexistunja/posts/pe nelitian-tengkuluk-exister-universitasjambimenggali-peradaban-tinggi-melayu1/627838920620548/ (diakses tanggal 23 Juli 2019)

https://id.wikipedia.org/wiki/Estetika, (diakses tanggal 5 Juli 2019) 